\title{
In the Interests of Clients or Commerce? Legal Aid, Supply, Demand, and 'Ethical Indeterminacy' in Criminal Defence Work
}

\author{
Cyrus Tata*
}

As a professional, a lawyer's first duty is to serve the client's best interests, before simple monetary gain. In criminal defence work, this duty has been questioned in the debate about the causes of growth in legal aid spending: is it driven by lawyers (suppliers) inducing unnecessary demand for their services or are they merely responding to increased demand? Research reported here found clear evidence of a change in the handling of cases in response to new payment structures, though in ways unexpected by the policy's proponents. The paper develops the concept of 'ethical indeterminacy' as a way of understanding how defence lawyers seek to reconcile the interests of commerce and clients. Ethical indeterminacy suggests that where different courses of action could each be said to benefit the client, the lawyer will tend to advise the client to decide in the lawyer's own interests. Ethical indeterminacy is mediated by a range of competing conceptions of 'quality' and 'need'. The paper questions the very distinction between 'supply' and 'demand' in the provision of legal services.

* Centre for Sentencing Research, Law School, Strathclyde University, Glasgow G4 OLT, Scotland

Cyrus.Tata@strath.ac.uk

I wish to thank the following people for their insightful comments on, and advice about this paper and the ideas contained in it: Lynn Mather, Tamara Goriely, Richard Moorhead, Ed Cape, Elaine Samuel, John Flood, Peter Duff, Julian Webb, Roger Bowles, Lee Bridges, and the anonymous reviewers of this paper. I also wish to acknowledge Frank Stephen with whom I led the research discussed here; as well as Giorgio Fazio, Alex Christie, and Lorraine Sweeney, each of whom worked on different aspects of the study discussed here. I also wish to thank all of the prosecution and defence practitioners, members of the judiciary, officials, and representatives of client groups who assisted with access to data, or, agreed to be surveyed, or, interviewed. 


\section{INTRODUCTION}

Do lawyers place the interests of clients before their own self-interest? The client service ethic is commonly regarded as one of the most important distinctions between lawyers as professionals rather than mere businesspeople. $^{1}$ Yet research into lawyer-(non-corporate) client relations has, broadly-speaking, suggested that this picture is misleading: lawyers, motivated by (or at least well aware of) their own self-interest, and justified by a weary cynicism about most clients, use a variety of techniques to influence and/or dominate clients. ${ }^{2}$ In the criminal sphere, (where control of clients by lawyers has been identified most acutely), legal aid policy officials have been heavily influenced by a reading of the 'supplier-induced demand thesis ${ }^{3}$ which suggests that lawyers (suppliers) tend to create demand and carry out non-essential work for their own financial gain. Governments have employed this thesis to allege that lawyers 'milk' the legal aid system: for example, by encouraging clients to plead guilty at the last minute because it is in the financial self-interest of lawyers to do so. The supplier-induced demand thesis has recently been countered by other scholars who argue that

1 The notion of putting the client's interest before one's own is crucial to professional claims and the key distinction from commerce. 'Professionalism is not concerned with self-interest, but with the welfare of the client': T.H. Marshall [full ref, please?? ] (1939), cited by G. Munhgam and P.A. Thomas, 'Solicitors and Clients: Altruism or Self-Interest?' in The Sociology of the Professions, eds. R. Dingwall and P. Lewis (1983) $130-51$, at 136.

2 See for example: A. Blumberg, Criminal Justice (1967); J. Baldwin and M. McConville, Negotiated Justice (1977); A. Bottoms and J. McClean, Defendants in the Criminal Process (1976); M. McConville, J. Hodgson, L. Bridges, A. Pavlovic, Standing Accused (1994); T. Goriely, P. McCrone, P. Duff, C. Tata, A. Henry, M. Knapp, B. Lancaster, A. Sherr, The Public Defence Solicitors' Office: An Independent Evaluation (2001); C. Tata, T. Goriely, P. Duff, A. Henry, P. McCrone, M. Knapp, 'Does Mode of Delivery Make a Difference to Criminal Case Outcomes and Client Satisfaction?' (2004) 50 Crim. Law Rev. 120-35; R. Ericson and P. Baranek, The Ordering of Justice (1982); A. Mulcahy, "The Justifications of "Justice"” (1994) 34 Brit. J. of Crim. 411-30; D. Rosenthal, Lawyers and Clients - Who's in Charge? (1974); A. Sarat and W. Felstiner, Divorce Lawyers and their Clients (1995); C. Smart, The Ties that Bind (1984); L. Mather, C. McEwen, R. Maiman, Divorce Lawyers at Work (2001); L. Mather, Plea Bargaining or Trial? (1979); R. Flemming, 'Client Games' (1986) 11 Am. Bar Foundation Research J. 253-77.

3 G. Bevan, 'Has there been supplier-induced demand for legal aid?' (1996) 15 Civil Justice Q. 98-114; A. McGuire, J. Henderson, G. Mooney, The Economics of Health Care (1998); A. Gray, P. Fenn, N. Rickman, An Empirical Analysis of Standard Fees in Magistrates' Court Cases (1999a); A. Gray, P. Fenn, N. Rickman, 'Controlling Lawyers Costs through Standard Fees: an economic analysis' in Access to Criminal Justice, eds. D. Wall and R. Young (1999b) 192-216; A. Gray, N. Rickman, P. Fenn, 'Professional autonomy and the cost of legal aid' (1999c) 51 Oxford Economic Papers 545-58; A. Gray, 'The Reform of Legal Aid' (1994) 10 Oxford Rev. of Economic Policy 51-67. Although Bevan's analysis did not concentrate on criminal defence work, it has nonetheless been used by governments in their search for answers to the causes of growth in criminal legal aid expenditure. 
the reason for sharp increases in spending criminal legal is demand-led (most particularly through the actions of the state).

This paper reports some of the findings of recent research into the effects of a major change in legal aid remuneration structures for criminal defence work. The abolition of a 'time and line' system ${ }^{4}$ and its replacement with a system of fixed payments in Scotland was premised on the idea that under the previous time and line system, defence solicitors ${ }^{5}$ had been profligate in their provision of legally aided defence work and that fixed payments would provide incentives for greater self-discipline: only carrying out necessary work. Yet what impact, if any, has this new policy had on the quality of service provided to clients? ${ }^{6}$ If because of financial drivers, lawyers change the way in which they deal with clients, and the advice they give to them as to how to plead, can we say that the service given to clients is now, overall, better or worse or the same?

But what do we mean by 'better' or 'worse'? This paper argues any such assessment requires a conception of 'need' and 'demand', implying what the defence lawyer ought to do in any given case. It is suggested that there is legitimate disagreement about this, a range of normative perspectives of what constitutes 'good quality' or 'proper' defence work. The concept of 'ethical indeterminacy' may be useful in helping us to think about the dynamic relationship between lawyers' self-interest and the interpretation of clients' interests. These different perspectives on quality mesh together with lawyers' own self-interest. Later in the paper, it is proposed that the findings point towards the development of a broader version of ethical indeterminacy, which questions whether, at an empirical level, 'supply' and 'demand' are or could be mutually distinguishable.

\section{THE SUPPLIER-LED AND DEMAND-LED THESES}

The causes of growth in legal aid expenditure for criminal cases have been hotly debated at both policy and methodological levels. One of the main sources of the heat is the question of who is to blame for the rise in expenditure. For example, Wall has observed that:

the [supplier-induced demand] thesis dominates debate over legal service provision ... [T] he blame for the increase in expenditure inevitably falls squarely at the feet of the legal profession. ${ }^{7}$

4 An itemized billing system in which the cost of the lawyer's work is based on the types of work conducted and the amount of time spent.

5 Summary criminal defence work is carried out by the solicitor branch of the legal profession.

6 This is not to suggest that finance should be seen as the only or main influence on lawyer advice and behaviour. Rather, it may be seen as one influence among several: lawyers rely on a range of forms of capital - financial, social, and cultural.

7 D. Wall, 'Legal Aid, Social Policy, and the Architecture of Criminal Justice' (1996) 23 J. of Law and Society 649-69, at 652-3. 
Indeed, much of the debate is also about whether lawyers 'exploit' or 'milk' the system of remuneration by conducting unnecessary work. Critics of the supplier-induced demand thesis have sought to expose its censorious undertone. For example, Cape and Moorhead observe:

The idea that lawyers increase either the number of cases they take on or the costs incurred on those cases simply to ensure target incomes implies quasifraudulent behaviour by large numbers of the legal profession. ${ }^{8}$

Thus, what is at stake is not simply an empirical question about what drives legal aid expenditure, but one which impugnes the moral legitimacy and professionalism of criminal defence practice. More broadly still, it reopens the fundamental question of whether lawyers work in the best interests of their clients or mainly in their own self-interests. ${ }^{9}$

Alarmed by the rising cost of legal aid for criminal defence work and inspired by new public management ${ }^{10}$ agendas, governments in a number of countries have attributed sharp rises in spending on criminal legal aid to the behaviour of defence lawyers themselves. The supplier-induced demand hypothesis proposes two key reasons why professionals (whom the thesis implicitly conceives of as primarily acquisitive rational economic actors) induce and inflate demand for their services. First, there is the 'principal/ agent' problem in which the there is a conflict of interests (or incentives) between the client (principal) and the supplier of the service (agent). Furthermore, there is 'asymmetry of information' between the professional and the client. This makes it difficult for the client to control the direction of the work. The second fundamental problem is the concept of 'moral hazard', which is adapted from insurance work, where being insured changes the behaviour of the client:

The crucial problem here is that individuals lose interest in the costs of services being supplied ... Moral hazard threatens the benefits of insurance as this leads to escalating costs of insured services. ${ }^{11}$

In criminal legal aid a third party (usually an agency of government) almost always pays. However, even if it was affordable:

payment by the client is not a solution ... because the client also encounters a principal/agent problem. The client relies on the ... lawyer to decide the services to be supplied. ${ }^{12}$

8 E. Cape and R. Moorhead, Demand-induced Supply? Identifying Cost Drivers in Criminal Defence Work: Report to the Legal Services Commission (2005) 9. See, also, L. Bridges, The Myth of Case Splitting, unpublished paper (2001).

9 See, for example, Mungham and Thomas, op. cit., n. 1; Z. Bankowski and G. Mungham, Images of Law (1976); P. Carlen, Magistrates' Justice (1976); Baldwin and McConville, op. cit., n. 2; McConville et al., op. cit., n. 2.

10 H. Sommerlad, 'Some Refelections on the Relationship between Citizenship, Access to Justice, and the Reform of Legal Aid' (2004) 31 J. of Law and Society 345-68.

11 Bevan, op. cit., n. 3, at p. 102

12 id., at p. 103. 
For supplier-induced demand theorists, the idea that professionals such as lawyers are inclined to 'draw considerable income from the scheme' ${ }^{13}$ is viewed as natural behaviour for such rational economic actors.

Governments, however, have used the supplier-induced demand hypothesis as an instrument of moral censure. The thesis provided 'proof' that defence lawyers' put cynical self-interest before that of their clients. Moreover, governments tend to seize on the supplier-induced demand hypothesis as 'a more or less uncontested official view of how legal aid operates and why legal aid expenditure has been driven ever upwards. ${ }^{14}$ In their recent review of the evidence, Cape and Moorhead also underline the political use of the supplier-induced demand hypothesis:

It is easy to understand the desire of government to reform criminal justice, without properly funding the defence side of the equation. Supplier-induced demand provides a convenient political justification for so doing. But our analysis shows that the system itself creates significant demand ... is

Other scholars have argued that supplier-induced demand thesis ignores the major contributors to inflation in legal aid: the activities of the state. ${ }^{16}$ Demand-induced supply theorists have criticized supplier-induced demand theory for ignoring 'system incentives' and instead assuming that 'raw, invariant self-interest alone' explains spending patterns. ${ }^{17}$

This article seeks to contribute to this supplier-induced demand/demandinduced supply debate (and thus also the question of lawyer-client relations) by presenting and discussing the implications of recent research into the effects of a radical change in the system of legal aid payments made to defence lawyers. It asks whether the findings support either the supplierinduced hypothesis or the demand-induced hypothesis. I suggest that the concept of 'ethical indeterminacy' may be a useful way of conceptualizing how lawyers have to interpret and reconcile the apparently competing demands of client interests on the one hand and self-interest on the other.

\section{ETHICAL INDETERMINACY}

This article aims to add to the supplier-led versus demand-led debate by developing a nascent concept of 'ethical indeterminacy' in lawyer decision making, a concept which arises from this and other recent research. We have seen that the most contentious question is whether lawyers alter their

13 E. Blankenberg, 'Comparing Legal Aid Systems in Europe' (1992) 11 Civil Justice Q. at 176.

14 E. Samuel, 'Criminal Legal Aid Expenditure: Supplier or System Driven?' in Access to Criminal Justice, eds. R. Young and D. Wall (1996) 217-53.

15 Cape and Moorhead, op. cit., n. 8, at p. 70

16 id.; Bridges, op. cit., n. 8; Wall, op. cit., n. 7.

17 Samuel, op. cit., n. 13, at p. 227 
handling of cases for financial gain even at the expense of the interests of their clients. It has also long been recognized that formal rules governing professional conduct are limited in governing the ethical dilemmas which lawyers must address every day. ${ }^{18}$ As in so many other areas, rules run out, are abstract, general, vague, contradictory. Moreover:

[e]ven when the norms are straightforward and consistent, the facts and issues in cases are frequently not. [...] [T] he professional account overstates the power of formal rules, does not sufficiently acknowledge their indeterminacy, ignores the weakness of enforcement of rules, and fails to recognise the fragmented nature of the profession. ${ }^{19}$

How, then, can we make sense of how lawyers work when faced with financial incentives which might contradict how a lawyer would otherwise advise a client and handle the case? At first blush, there is a straightforward clash between the ethic of service and the requirement to maintain a business: between altruism and self-interest. I seek to suggest that the relationship between these two is more subtle and complex than is depicted by a straightforward contradiction between lawyer self-interest and client interest.

Arising from their study of the performance of public defence solicitors and private firm legal aid solicitors in Scotland, ${ }^{20}$ Goriely et al. ${ }^{21}$ suggest that there may be a way of understanding how lawyers adapt their pleading advice to clients in a way which may be both personally advantageous but without conclusively and necessarily diminishing their clients' interests. ${ }^{22}$ Using a sample of cases matched in terms of case characteristics, it was clear that public defence solicitor cases tended to plead guilty earlier in the process than private firm cases in otherwise similar circumstances. The differences in guilty plea rates were not huge, but statistically highly significant and were confirmed and explained by interviews with professionals and clients. Whether pleading guilty early was in the best interests of clients is a moot point. If one is prepared to take the risk of pleading not guilty until the day of trial, the chances that the case will collapse increase sharply. On

18 See, for example, articles in the recent 2006 special issue of Legal Ethics: E. Cape and J. Webb, 'Editorial: The Ethics of Criminal Justice Professionals in an Era of change', 1-5; L. Bridges, 'The Ethics of Representation on Guilty Pleas', 80-100; E. Cape, 'Rebalancing Criminal Justice Process: ethical challenges for criminal defence lawyers', 56-79, all in (2006) 9 Legal Ethics.

19 L. Mather, R. Maiman, C. McEwen, " "The Passenger Decides on the Destination and I Decide on the Route": Are Lawyers "Expensive Cab Drivers"?' (1995) 9 International J. of Law and the Family 286-310, at 7-11???.

20 Despite the recent introduction of public defence solicitor offices in Scotland, the vast majority of defence work is conducted by solicitors working in private firms which are paid for the work on those individual cases by SLAB (that is, at the time of writing (2007), there is no block contracting).

21 Goriely et al., op. cit., n. 2.

22 id.; Tata et al., op. cit., n. 2. 
the other hand, clients and their lawyers have to balance this up against the chances of conviction after trial and the stress and anxiety involved, as well as the vagaries of sentence-discounting for a guilty plea. In its discussion of the findings, the research team briefly suggested that consideration of a concept of 'ethical indeterminacy' might help to explain the interaction between lawyer incentives and the intrinsic interests of each case:

[We do] not contend that professional, dedicated people will abandon cherished principles simply for monetary gain. Rather, [the research] suggests that modifications in behaviour will be greatest in areas of ethical indeterminacy: that is where the choice is between two courses of action, both of which have advantages and disadvantages, and where ethical practitioners genuinely differ about which is the better. In making difficult and evenly balanced judgements, greater weight is placed on the advantages that flow from a course of action that is in one's own interests. Less weight is placed on those that flow from actions that run contrary to one's interests.

Furthermore, one should not expect the relationship between payment and behaviour to be simple or direct. Solicitors rely on various forms of social capital to be able to practice - most obviously a client base and credibility with the courts, [prosecution] service and colleagues. They would be loath to jeopardise either clients or credibility. [...] One might also expect that the relationship between financial incentive and behaviour would be mediated through values.

In this passage, Goriely et al. put forward the concept of ethical indeterminacy to help to explain plea advice decision-making. How do defence lawyers respond to a shift in financial incentives? Can they adjust their handling of cases and advice to clients without compromising the interests of clients, or, will quality of the service provided to clients be an inevitable casualty? Much of the research literature critical of defence lawyer work ${ }^{23}$ or even that which seeks to defend it as pragmatically reasonable ${ }^{24}$ relies on an implicit conception of quality. To evaluate the conduct of defence lawyers requires some answer to the question of what else the lawyer could have done and ought to have done in order to meet the client's best interests.

The parallel concepts of 'quality' and 'best interests of the client' are highly contestable and the subject of competing perspectives. Each of these perspectives is invoked by and constitutes the routine discourses of lawyers in guiding, justifying, and re-presenting different courses of action and advice to clients, to other professionals, and to themselves. ${ }^{25}$

23 See, for example: Blumberg, op. cit., n. 2; Baldwin and McConville, op. cit., n. 2; McConville et al., op. cit., n. 2; Ericson and Baranek, op. cit., n. 2; Mulcahy, op. cit., n. 2; Flemming, op. cit., n. 2.

24 For example, M. Travers, Persuading the Client to Plead Guilty (1992).

25 See, also, in this vein (but in the context of plea-negotiation), Mulcahy, op. cit., n. 2; S. Roach Anleu and K. Mack, 'Pleading Guilty and Professional Relations in Australia' (2001) 22 Justice System J. 155-84. 


\section{Normative justifications of defence work and ethical indeterminacy}

The concept of ethical indeterminacy suggests that the relationship between financial arrangements and lawyer behaviour is less straightforward than that either portrayed in public by professional law bodies (namely, that lawyers only act in the clients' interests regardless of financial self-interest), or, that portrayed by behaviourist economics (namely, that lawyers, like everyone else, are determined more or less directly by financial incentives). Rather, lawyers rely on a range of forms of capital (social, cultural, as well as economic), and we should expect the relationship between financial payment structures and the handling of cases to be complicated by and mesh with cultural practices enveloped in more enduring ideologies. Ethical indeterminacy suggests that changes in lawyer practices are mediated and negotiated by a range of competing normative justifications about the character of 'good' (or even 'adequate') defence work. The proper role of the lawyer (and indeed as a professional) is highly contestable ${ }^{26}$ and there is a range of very different perspectives underlying the idea of 'quality' in criminal legal practice. Each of these perspectives is based on underlying assumptions about 'real' case need. ${ }^{27}$ In this section, I attempt to sketch five possible different perspectives. However, I am not seeking to claim that these 'ideal types' are, by any means, definitive: the exact number and nature of these different perspectives is debatable. Rather, in this section, my aim is to envisage different ways in which lawyers can approach the same situation in a range of reasonably defensible ways - thus combining self- and client interests. ${ }^{28}$ Later in this paper, I attempt to illustrate how practitioners and policy officials are able to draw on these different normative values (and combinations of them) as a reservoir of resources of principled justifications for their decisions and advice in individual cases. Each perspective is driven by an essentialist conception of 'real' need. By saying this, I do not mean to suggest that the use of such an array of justifications is improper or dishonest but. rather, that accounts by professionals are mediated and refracted through a range of normative lenses.

26 See, in this regard, about lawyers more generally, especially in respect of civil work, T. Goriely, 'Debating the quality of legal services' (1994) 1 International $J$. of the Legal Profession 159-72.

27 Here my thinking has been influenced by the rich literature on the sociology of professions; also, by research and long-standing debates in criminal justice and process, most particularly plea bargaining.

28 In a smiliar vein, Mather et al., op. cit., n. 19, at p. 307 observe from their interviews with divorce lawyers:

Lawyers describe an array of tactics ... that they use to influence their clients' decisions. Invariably, such tactics are invoked 'for the client's good', since the attorney knows from experience that an unreasonable client can harm himself, his former spouse, and his children. But the lawyer also knows that by representing unreasonable clients one can gain a reputation for being an unreasonable lawyer. 
The first of these sets of values, or perspectives, might be the traditional trait perspective $^{29}$ with its emphasis on distinct legal knowledge, skill, accuracy, whereby technical knowledge is applied to case 'facts'. Service to the client (and indeed the wider public interest) comes before narrow selfinterest. The invocation of the trait perspective suggests a formalistic approach to problem-solving: there is no acknowledgement that cases are constructed by the process; the facts are the facts; the rules are the rules; there are correct answers waiting to be found to legal problems. Thus, cases are either inherently simple or inherently difficult. As we shall see, the trait perspective is used to justify the introduction of changes to remuneration structures. A second perspective is the bureaucratic-efficiency model which emphasizes the importance of mass casework and 'efficiency' on the basis of the supposed core 'needs' of different categories of cases. In this perspective, there is an emphasis on the criminal process as a conveyor belt in which the best interests of the case are served by following standardized practices. ${ }^{30} \mathrm{~A}$ voracious desire for early guilty pleas is justifiable because from experience one can expect that the accused/defendant is likely to plead guilty anyway, and so clients (and/or others) will be rewarded with a discounted sentence. Clients are regarded as wanting to 'put off the evil day'. Pleading is therefore seen as a largely tactical matter of gamesmanship, enveloped in an 'ideology of triviality'. ${ }^{31}$ Adversarialism is a third perspective with its emphasis on suspicion of and protection from the state. This justifies, for example, the need to put the prosecution to proof; a willingness to obstruct and delay the prosecution; the strongest presumption of innocence; and the moral aversion to plea bargaining. A quality indicator might be the overall acquittal rate. A fourth perspective relates to radical lawyering where there is a conception of community need because of social disadvantage, which requires to be tackled. Law is seen as an instrument for social change or amelioration of oppression. A fifth perspective of quality (seen most obviously in civil work but also drawn in criminal work) is client-centred work. This would tend to emphasize the different approaches of clients to different problems and the importance of their particular concerns and emotional needs. Although this may be seen as a client participation model, ${ }^{32}$ a client-centred perspective can also be selectively used to explain particular decisions guided by the lawyer as those motivated by the client; and to emphasize the voluntariness of decisions of clients who 'instruct' their lawyers. ${ }^{33}$ Thus, it can also emphasize, for example, the fickleness and fecklessness of clients in the

29 For example, Marshall, op. cit., n. 1.

30 In certain respects this perspective is compatible with the early attempts to fix and standardize conceptions of 'quality' in legal services. As we shall see, those who proposed and justify the imposition of fixed payments have drawn on other perspectives of quality in combination with 'bureaucratic-efficiency'.

31 D. McBarnet, Conviction (1981).

32 For example, as advocated by Rosenthal, op. cit., n. 2.

33 Roach Anleu and Mack, op. cit., n. 25. 
alteration of pleading practices which might otherwise seem unreasonable if controlled by the lawyer.

With these normative perspectives in mind, let us turn to the research examining the impact of a change in the structure of financial payments to legally aided defence lawyers in Scotland.

\section{THE INTRODUCTION OF FIXED PAYMENTS IN SCOTLAND ${ }^{34}$}

The new system of 'fixed payments' (also known as 'fixed fees') for summary criminal legal aid was prescribed in the Criminal Legal Aid Fixed Payments (Scotland) Regulations 1999 as amended by the Criminal Aid (Fixed Payments) (Scotland) Amendment Regulations 2002. It was implemented for summary criminal proceedings (that is. non-jury triable cases) from 1 April 1999.

In Scotland, there are six basic types of legal aid assistance in summary criminal proceedings. However, the primary form is full 'summary legal aid', which is only available after an initial not guilty plea has been tendered. Solicitors must normally lodge an application with the Scottish Legal Aid Board (SLAB) within 14 days of a not-guilty plea. SLAB is required to administer (or refuse) grants of legal aid by taking into account both financial factors (a means test) and a merits test (that it is in the 'interests of justice' for legal aid to be granted). ${ }^{35}$ Much of the discussion about summary legal aid has concentrated on its cost, particularly in the intermediate Sheriff Courts: ${ }^{36}$ during the 1980 s and until the mid 1990s average case costs rose rapidly. ${ }^{37}$

34 Scotland has a separate system of criminal law and procedure from that of England and Wales, with appeals being heard by the Court of Criminal Appeal in Edinburgh (there is no appeal in criminal cases to the House of Lords). The legal profession of Scotland is separate from that of England and Wales, as is the independent prosecution service - Crown Office and Procurator Fiscal Service (COPFS).

35 Legal Aid (Scotland) Act 1986 s. 24(3).

36 In Scotland there are two types of courts hearing summary matters. The Sheriff Courts (presided over by sheriffs who are professional lawyers by background) and hear both solemn (jury-triable) and summary (non-jury-triable) cases. The District Courts are largely presided over by lay justices (although in Glasgow they are presided over by stipendiary magistrates and have the same sentencing powers as the summary sheriff courts) and hear summary cases only. Unlike England and Wales, the accused person has no right to elect for jury trial. Sheriffs (including Glasgow District stipeniary magistrates who have effectively the same powers as sheriffs) hear more than three-quarters of all criminal cases in Scotland.

37 See Goriely et al., op. cit., n. 2, T. Goriely, C. Tata, and A. Paterson, Expenditure on Criminal Legal Aid: report of a Comparative Pilot Study of Scotland, the Netherlands, and England and Wales (1997); F. Stephen, Legal Aid Expenditure in Scotland: Growth, Causes, and Alternatives (1998); C. Tata, 'Comparing Legal Aid Spending: the Promise and Perils of Jurisdiction-centred Approach to International Legal Aid Research' in The Transformation of Legal Aid, eds. F. Regan, A. Paterson,

T. Goriely, D. Fleming (1999); F. Stephen, 'Reform of Legal Aid in Scotland' (2001)

8 Hume Papers on Public Policy 23; Tata et al., op. cit., n. 2. 
And it is the effect of changes to summary legal aid, especially in the Sheriff Court, on which the research discussed here concentrates.

The new system was a radical departure from 'time and line billing, 38 Now, under fixed payments, payments are made for blocks of work. Solicitors receive $£ 300$ (plus VAT) per case in the District Court and $£ 500$ (plus VAT) per case in the Sheriff Court. These sums were expected to cover all work up until trial or plea in mitigation. After the first 30 minutes of the trial further payments are available, as well as, among other things, for bail appeals and deferred sentences. ${ }^{39}$ Solicitors can no longer claim additional payments for costs associated in preparing the case (including investigating the prosecution's case, travel, waiting time), although there are a few exceptions (for example, medical reports), which can be claimed in addition to the basic fixed fee.

The fixed payment system is considerably simpler than standard fee arrangements introduced into magistrates' courts in England and Wales in 1993. The fixed payments cover all work and almost all cases; there are no higher and lower standard fees each with lower and higher limits. The only variation in cases which initially plead not guilty depends on jurisdiction of prosecution (that is, District or Sheriff Court) and whether a trial goes beyond the first 30 minutes. Importantly, in Scottish criminal procedure the accused person $^{40}$ cannot elect for trial by jury: there are no 'either way' cases. In almost all cases, whether a case is prosecuted on solemn indictment or summary complaint is at the discretion of the prosecution service. There are no case categories with lower and higher limits as there are for standard fees in England and Wales. ${ }^{41}$

What research there has been into the impact of standard fees in England and Wales has suggested very different findings. On the basis of an econometric model, Gray et al. suggested that solicitors seek to concentrate work at the threshold levels of remuneration steps, ${ }^{42}$ while Bridges suggests that the very complexity of the standard fee system has been one of the reasons for its success in stabilizing costs. ${ }^{43}$ As we have seen, the Scottish system of fixed payments is relatively 'fixed': it has proved to be very difficult for solicitors to persuade SLAB that the case they are dealing with is sufficiently complex or unusual that it should paid on a 'time-and-line

38 An itemized billing system in which the cost of the lawyer's work is based on the types of work conducted and the amount of time spent.

39 For example, in the Sheriff Court $£ 100$ for the first day of trial a further $£ 200$ for the second day.

40 'Accused person' is the equivalent term in Scotland for 'defendant'.

41 An immediate plea of guilty (the equivalent of 'category 1' in standard fees) cannot be dealt with under summary legal aid (fixed payment), but through 'advice by way of representation' (ABWOR), where the solicitor is paid $£ 70$ for all work up to the first appearance and up to $£ 150$ if a subsequent diet is set

42 Gray et al., op. cit. (1999a; 1999b), n. 3.

43 Bridges, op. cit., n. 8. 
basis'. ${ }^{44}$ Furthermore, unlike England and Wales, there are no 'graduated steps' in the payment regime other than the number of trial days. The defence has no control over whether a case is prosecuted in the District or Sheriff Courts, or indeed whether or not the case is set for summary (nonjury triable where fixed fees would apply) or solemn (jury triable, where time and line billing would apply) jurisdiction. However, both fixed payments and controlled fees base their justification on the idea of overall cost neutrality which is common to contracting, franchising, standard fees: the notion of 'swings and roundabouts'.

\section{1. 'Responsibilization' and swings and roundabouts}

In contrast to the previous 'time and line' (or 'proportional') payment system, a system of fixed payments might be criticized for not paying solicitors for the work actually done in individual cases. However, those in favour of fixed payments tend to argue that this is a case of 'swings and roundabouts': typically, what a solicitor loses on the roundabouts she or he gains on the swings. ${ }^{45}$ In other words, it is expected that every so often a solicitor has to deal with relatively more difficult or unusual cases, which require greater attention and time. Such cases, under a fixed fee system, are less well paid for the work done. However, these are cancelled out, according to the 'swings and roundabouts' argument, by the vast majority of standard cases which are regarded as run-of-the-mill, thus requiring much less work by the solicitor. So although on a case-by-case basis the system of payment is not proportional to the work done, over the longer run gains and losses should cancel each other out. The thinking was, and continues to be, that solicitors make the appropriate professional judgement as to the amount of preparatory work required by any particular case. ${ }^{46}$ Here a trait perspective of quality and need is applied by proponents of fixed payments to advance the swings and roundabouts argument:

Most cases - they are overpaid in terms of the likely cost of the case, if you take the many District [Court] cases and even Sheriff Court cases the amount of work that solicitors will have to do will not come to $£ 500$. [Face-to-face stakeholder Interview 4, SLAB official 5].

44 Following challenges to the legality of the fixed payments system, in June 2002 this simple system of fixed payments was amended to allow for unusually complex and difficult cases (known as 'exceptional cases') to receive payment under time and line. The determination of what an exceptional case is made by SLAB, which reported in 2004 that it granted only 28 applications out of 158 applications for time and line on the basis of an 'exceptional case': SLAB, Proposals for the Review of Summary Criminal Legal Assistance (2004) at para. 3.34.

45 'Swings and roundabouts' is also central to the logic of the Carter Review in England and Wales. See, for example, House of Commons Constitutional Affairs Committee (2007) Implementation of the Carter Review of Legal Aid: third report of Session 2006-7 vol. II, Q55-70

46 See, also, SLAB, op. cit., n. 44, para. 3.33 . 
The whole principle of fixed payments is that it remunerates adequately for the average case. So anything that involves more than the average in terms of preparation, precognitions, ${ }^{47}$ or, preparation for trial etc will require more input from the solicitor and therefore will be less profitable for them. But then they will be balanced by the other cases, which are more straightforward, which perhaps plead at an earlier stage; which have fewer precognitions; which don't go to trial and those cases you would expect the solicitor to be, if anything, overremunerated for the work they've actually done. And over the whole we expect that to balance out. [Face-to-face stakeholder Interview 4, SLAB official 5].

Like block contracting, the fixed payment system is argued by its proponents to be simpler than a system of proportional payment. The notion of fixed payments, like contracting, relies on the idea of 'responsibilizing' solicitors. Rather than a legal aid authority having to determine what is reasonable and necessary in any particular case, responsibility is transferred to the individual practitioner. $^{48}$ As professionals, the proponents of fixed payments claim, solicitors know what is necessary in any particular case: the incentive for the 'excessive' supply of legal services ('moral hazard' in supplier-induced demand terminology) is diminished by making the solicitor a 'cost centre'.

\section{THE FIXED PAYMENTS RESEARCH ${ }^{49}$}

The research into fixed payments discussed here used a combination of quantitative and qualitative analysis to explore the impact on, among other things: solicitor firm incomes; SLAB expenditure; the handling of cases by solicitors; the stage of resolution of cases. A series of face-to-face interviews was conducted with senior personnel (known, perhaps somewhat dubiously, as 'stakeholders'); a postal survey made of defence solicitors ${ }^{50}$ to glean basic information; a telephone survey made of defence solicitors, and a telephone survey of rank and file prosecutors (known as 'depute procurators fiscal'). ${ }^{51}$ These telephone surveys consisted of both closed and open interview questions, and were followed-up with face-to-face interviews with defence solicitors and depute fiscals (described as non-stakeholder face-to-face interviews). We were also given access to SLAB disaggregated data files, and to Crown Office and Procurator Fiscal Service (COPFS) disaggregated

47 The term 'precognition' is explained below.

48 This shift parallels responsibilization strategies detected in other fields: see D. Garland, The Culture of Control (2001).

49 F. Stephen and C.Tata, Impact of the Introduction of Fixed Payments into Summary Legal Aid: Report of an Independent Study (2007). The study was commissioned by the Scottish Executive and ran from December 2003 to January 2005 which was followed by submission of the research report. The report was eventually released and published by the Scottish Executive in 2007.

50 All defence solicitors referred to were actively engaged in summary criminal legal aid.

51 Scotland has a distinct prosecution service. Summary cases are prosecuted by Procurators Fiscal and their Deputes - colloquially known as 'depute fiscals' or 'fiscals'. 
data files. The sample for this quantitative analysis of SLAB data was 19972002 and for COPFS data it is from 1991 to 2003. The statistical analysis of disaggregated data allowed for more controlled analysis to be conducted than is possible by using aggregated data. ${ }^{52}$ The research reported here concentrates on the Sheriff Courts, where the level of expenditure is far higher than in the District Court; as is the ratio of legally aided persons to persons proceeded against. ${ }^{53}$ In this paper, I concentrate on reporting and discussing the impact of fixed payments on case handling and case trajectories.

At the time of announcement (and subsequent introduction in 2001) opponents of fixed payments predicted that it would lead to diminishing incomes for solicitors. There is not space here to report and discuss at any length the impact of fixed payments on legal aid expenditure or on firm income. ${ }^{54}$ Nonetheless, it is important to preface the reporting of the findings about case handling and case trajectories by stating that fixed payments hit the income of specialist defence firms particularly hard. However, by 2000-1 the income levels of these specialist firms began, on average, to recover and by $2001 / 2$ they had returned to the levels prior to the introduction of fixed payments. Both survey and interview evidence confirms and explains quantitative evidence showing that (especially specialist) firms adapted to fixed payments by sharply increasing the caseload undertaken by individual specialist defence solicitors (see Table 1).

Table 1: Firms, cases, and incomes before and after fixed payments

\begin{tabular}{llllll}
\hline & \multicolumn{2}{l}{ Pre-Fixed Payments } & \multicolumn{3}{l}{ Post-Fixed Payments } \\
\hline Financial Year & $1997-8$ & $1998-9$ & $1999-2000$ & $2000-1$ & $2001-2$ \\
Active Firms & 791 & 749 & 699 & 691 & 660 \\
Cases per Firm & 74.61 & 76.13 & 83.24 & 90.23 & 105.20 \\
Fee Income per Firm & $£ 47,451$ & $£ 42,572$ & $£ 48,587$ & $£ 53,837$ & $£ 58,269$ \\
\hline
\end{tabular}

Table 1 also shows that the average number of Summary Legal Aid cases has risen since the introduction of fixed payments. In 2001/02 it was 38 per cent higher than in the year preceding the introduction of fixed payments. Over the same period average fee income per firm had risen by 37 per cent. ${ }^{55}$

52 Full details on qualitative and quantitative methods are provided in Stephen and Tata, op. cit., n. 49.

53 The research tested for whether there has been, overall, a major shift in cases to the Sheriff Courts from the District Courts. It found that there has not been any statistically significant change.

54 See Stephen and Tata, op. cit., n. 49.

55 The average figures in Table 1 obscure large differences between firms, because of the varying degree of involvement of different firms in summary legal aid. Further analysis was conducted to explore these differences and is available in Stephen and Tata, id. 
Broadly speaking, the fixed payments system only becomes profitable to firms if they adjust to the new structure by taking on considerably larger volume of cases than they did under 'time and line'.

\section{Client contact}

One further way in which many defence solicitors appear to have accommodated the new payment structure has been to reduce the level of contact with clients. ${ }^{56}$ Table 2 shows the results from the telephone survey of summary legal aid defence solicitors: whether, as a result of the introduction of fixed payments, their overall amount of client contact had increased, decreased or remained the same. Solicitors were then asked whether they believed that the overall level of client contact had increased, decreased, or remained the same among other defence solicitors as a result of the impact of fixed payments.

Table 2. Solicitor-Client Contact $^{57}$

\begin{tabular}{llllc}
\hline & Increased & Decreased & Same & Don't know \\
\hline Own Contact & $1.7 \%(1)$ & $30.5 \%(18)$ & $66.1 \%(39)$ & $1.7 \%(1)^{58}$ \\
Others' Contact & $0 \%(0)$ & $53.2 \%(33)$ & $33.9 \%(21)$ & $12.9 \%(8)$ \\
\hline
\end{tabular}

Follow-up semi-structured questions yielded a stronger indication than the closed survey questions that defence solicitors believed their own and other solicitors had reduced levels of client contact as a result of fixed payments. For example:

Decreased, I think there would be no doubt about. In order to do summary cases you must have a big volume otherwise it's just not profitable. So if you have a big volume obviously you can manage it easier but normally contact would be down to perhaps two or three meetings, two normally, [...] I write out to them and ask them if they can make an appointment with me to discuss this and to take their further instructions. So normally [...] that's the only contact I would have with them. [Telephone Interview 981494, defence solicitor]

From a client-centred perspective this might be seen to be deleterious, but not from a bureaucratic-efficiency perspective or a trait perspective where client contact is easily dismissed as unnecessary. SLAB officials sought to

56 Here the term 'client contact' refers not only to face-to-face meetings (including with persons held on remand), but also written correspondence, telephone correspondence, and so on.

57 Due to rounding, percentages may not add up exactly to 100 .

58 The 'don't know' category excludes two respondents who declined to answer the question in any way about their own practices but did in relation to their observations of other solicitors' contact levels. 
make a distinction between what is necessary to progress the case as opposed to superfluous client-care and had a responsibilizing effect. For instance:

\begin{abstract}
There might be things like prison visits, or, you know, the fact that there may be more onus on the solicitor to try and manage the client relationship to ensure that they only do what is necessary to progress the case. Whereas previously, [...] there would be things that they could certainly argue that they could legitimately do as part of the case. But that would probably fall more into sort of client care, that sort of stuff which they might be able to take a more stringent approach to given that they are the one that will sort of lose out from it. [Face-to-face stake-holder interview 5 SLAB official]
\end{abstract}

Thus, SLAB official interviewees deployed a particular perspective of what level and type of client contact is deemed essential, which was at odds with some (though not all) defence solicitors interviews. For SLAB, much of the client contact under 'time and line' had been a superfluous luxury. Here we can see how the question of what constitutes essential 'need' is highly contestable and is deployed to justify different claims about quality.

\title{
2. Case investigation and 'precognitions'
}

Unlike other English-speaking jurisdictions, traditionally in Scottish criminal procedure there is no formal systematic provision for advance disclosure of prosecution evidence to the defence. Instead, the prosecution has traditionally provided a list of witnesses to the defence lawyer who then normally arranges for them to be interviewed and statements taken (that is, precognitions). A precognition differs from a witness statement in that a precognition cannot be put to the witness in a trial. "Whereas a witness statement is essentially an account of what the witness has said, a precognition is a precognoscer's account of the witness's evidence. ${ }^{59}$ Through this practice of precognitions, the defence is able to assess the strength of the prosecution case and can thereby advise the client. Research conducted shortly before the introduction of fixed payments showed that many defence solicitors argued that precognitions were essential to proper defence work. ${ }^{60}$

It was widely reported that as a direct result of the impact of fixed payments the use of precognitions had dropped very sharply: 61 per cent of defence solicitors believed that they were making less use of precognitions as a result of the impact of the introduction of fixed payments; 35 per cent said that they were making the same use; and only 2 per cent said that they were making greater use of precognitions as a result of fixed payments. Opinions varied as to whether, after fixed payments had been introduced, precognitions remained essential to preparation: many defence solicitors said that they now rely on an informal summary of the evidence provided by the

59 D. Christie and S. Moody, The Work of Precognition Agents in Criminal Cases (1999) at 9 .

60 id. 
prosecution and that this filled the gap left by precognitions. ${ }^{61}$ The following observation was typical:

I suppose it became more competitive for precognition officers ${ }^{62}$ and you would obviously seek to have the cheapest precognition possible but gradually it became a case that I would do them myself or obtain a copy of the summary of police evidence. [Telephone Interviews 981566, defence solicitor].

Drawing on trait perspective notions of quality, SLAB officials argued that fixed payments encouraged defence solicitors to be more discriminating in their use of precognitions. Under time and line, it was argued, defence solicitors had over-used precognitions by exaggerating a need to precognose in inherently straightforward cases. In other words, defence lawyers had been excessively adversarial. For example:

Well, for many criminal cases I can see why there's no need - Because there's either evidence or there's not, so they will need to take a judgement as to whether or not it's necessary. [Stake-holder face-to-face interview 4, SLAB official]

Indeed, many defence solicitors interviewed under the fixed payments regime supported the view that fixed payments encouraged greater discipline in the deployment of precognitions as it ate into the solicitor's profit margin:

We used to precognose summary cases when we were being paid for it but now that we're not we tend not to unless it's a cases that we think specifically requires it, we are more selective in what we precognose. [Telephone Interview 981332, defence solicitor]

In this 'selective' use of precognitions we can see an example of ethical indeterminacy. Under 'time and line' it was in solicitors' financial interests to precognose in almost every case; now under fixed payments it is widely recognized that the opposite is true. Both the extensive and minimal use of precognitions could each be seen to be consonant with clients' interests. It seems to be impossible to draw the line between what is necessary and not that line is indeterminate and contingent on circumstances of the individual case, firm, individual solicitor, and client.

Many of the defence solicitors interviewed argued that although they tend not routinely to obtain precognitions anymore this had not necessarily impacted on the quality of their representation. Indeed, it was observed that under time and line the use of precognitions had been exhaustive and that the new system of informal disclosure worked, in their case, was different, but that the change operated without any detriment to their client's interests.

61 Despite two important decisions of the Privy Council and also a memorandum issued by Crown Office directing prosecutors to systematic early disclosure, the practice of early disclosure remains patchy. See C. Tata and F. Stephen, 'When Paying the Piper Gets the "Wrong" Tune' in Transforming Lives, eds. P. Pleasence et al. (2007).

62 Precognition officers/agents are employed by solicitors to take precognitions. 
I don't do any more work, I don't think I do any less work but rather than precognose I'll speak to the fiscal. [Telephone Interview 981332, defence solicitor]

\section{Plea advice decision making}

Many readers of this journal will be familiar with the point that, although the decision as how to plead technically belongs to the client who instructs the lawyer, a large research literature has shown that the agenda for this decision and client expectations are also shaped by the lawyer. ${ }^{63}$ Similar dynamics have also been found in the relationship between civil lawyers and their (non-corporate) clients; and indeed between lay people and a variety of professional advisers. ${ }^{64}$ However, the relatively frail social, educational, and economic resources of most clients in summary proceedings coupled with the immediate stress and anxiety that the criminal process brings means that most summary clients tend to be in a particularly poor position to take firm command of their defence.

In the study reported in this paper, clients were not interviewed. At the very outset we raised this matter with the Research Advisory Group, ${ }^{65}$ which oversaw the research. It decided that the research was not commissioned to seek the views and experiences of summary legal aid clients. The group concluded that it would be impossible for clients to assess whether fixed payments had impacted on their experiences of being represented. However, this is not to say that an appreciation of client perspectives was unimportant to this research. The research drew on the existing research literature into client experiences and perspectives, and two studies ${ }^{66}$ which, in different ways, examined the client experience in the Scottish summary courts research evidence which was contemporaneous with the period examined in this paper. Both studies show that many represented clients in the Scottish summary courts tended to have difficulty accurately explaining the charges

63 See, for example: Mather, op. cit., n. 2; Flemming, op. cit., n. 2; Blumberg, op. cit., n. 2; Baldwin and McConville, op. cit., n. 2; Bottoms and McClean, op. cit., n. 2; McConville et al., op. cit., n. 2; Goriely et al., op. cit., n. 2; Tata et al., op. cit., n. 2; Ericson and Baranek, op. cit., n. 2 ; Mulcahy, op. cit., n. 2; Carlen, op. cit., n. 9.

64 Rosenthal, op. cit., Sarat and Felstner, op. cit., Smart, op. cit., Mather et al., op. cit., all in n. 2.

65 A Research Advisory Group was established by the Scottish Executive Justice Department to oversee and advise the research it wished to commission. The group was chaired by a senior official in the Justice Department and consisted of representatives of: the Justice Department, the academic research team, SLAB, COPFS, the Law Society, Scotland's criminal bar associations, the judiciary, and two independent academic experts who are highly experienced in the conduct of the kind of research that was to be undertake (Professors Peter Duff and Roger Bowles).

66 Goriely et al., op. cit., n. 2; C. Tata, 'Transformation, Resistance, and Legitimacy: the menace of "innocent guilty pleas"'(2007), paper presented to the Law and Society Association annual conference, Berlin. 
against them (or indeed those amended charges to which they chose to plead guilty). Furthermore, clients tended to conflate legal culpability with moral culpability: they may plead guilty for a variety of reasons but often do not believe they are truly guilty in the broader meaning of the word. Nonetheless, most clients were willing to place their trust in their defence solicitor and take his/her advice. In contrast to the supposition that client satisfaction is almost entirely outcome-orientated, most clients accepted that they were not in a position to judge their solicitor's command of law, or overall advice. They did, however, feel able to judge their defence lawyer on client process issues (such as: listening; being kept informed; being treated with dignity; being easily contactable; feeling that the lawyer cared about and remembered them). ${ }^{67}$ This is not to argue that summary clients are completely passive and lawyer influence is limitless, or, that lawyers are the only important influence in the pleading process. But it is to suggest that the defence lawyer-defendant relationship is hardly one of equals; let alone one in which it can be said that a simple market-style consumer-sovereignty model prevails.

As part of a telephone survey, defence solicitors were asked whether, fixed payments had impacted on their advice to clients as to how to plead. They were then asked whether they thought fixed payments had impacted on the advice of other solicitors. That any solicitors said, in answer to a closed survey question, that their own individual pleading advice practice had been affected by payment structures was, in itself, surprising, and unexpected. In response to follow-up telephone and face-to-face interviews, the nuances of this impact were more apparent (discussed later in this section).

Table 3: Thinking about the overall workload, has the introduction of fixed payments had an impact on pleading advice to clients? ${ }^{68}$

\begin{tabular}{lllc}
\hline & Yes & No & Don't know \\
\hline Pleading advice - own & $10.2 \%(6)$ & $86.4 \%(51)$ & $3.4 \%(2)$ \\
Pleading advice - others & $36.1 \%(22)$ & $31.1 \%(19)$ & $34.4 \%(21)$ \\
\hline
\end{tabular}

67 See, for example: R. Moorhead, A. Sherr and A. Paterson (2003) 'Contesting Professionalism' Law \& Society Review 37(4) 765-808. Sherr et al. succinctly put it: '[T]he client's views on quality are invaluable but inherently limited.' (Sherr, Moorhead, Paterson (1994) 'What Clients Know' International Journal of the Legal Profession 10(1) 5-35. See also, (albeit with a different argument on outcomes and processes from Sherr et al.), P. Sanderson and H. Sommerlad (2002) 'Exploring the Limits to the Standardization of the Expert Knowledge of Lawyers' Syracuse Law Review 52 987-1016.

68 Percentages may not add up to 100 due to rounding.

69 The 'don't know' category excludes two respondents who declined to answer the question in any way about their own practices, but did so in relation to their observations of other solicitors. 
Statistical analysis of nationwide COPFS disaggregated data from 1991 to 2003 was conducted to determine whether there appeared to have been any changes in the resolution of cases as consequence of the introduction of fixed payments. In Scottish summary procedure there are three major formal court hearing stages: the pleading diet (the first hearing at which a plea is entered); the intermediate diet (which was made mandatory in 1996 and is a form of pre-trial review to check both prosecution and defence still wish to go to trial); and the trial. In line with previous Scottish summary process work, ${ }^{70}$ we analysed data according to these three main formal stages of procedure plus a fourth: cases which concluded on the day of trial but before evidence had been led (so called 'cracked trials').

The impact of fixed payments appears to have been to reduce the proportions of cases resolving at the first opportunity (pleading diet); increase the proportions of cases resolving at the intermediate diet; and slightly increase the proportions of cases resolving at the day of trial but before evidence has been led; and slightly reduce the proportions of cases resolving after evidence has been led. ${ }^{71}$ Using disaggregated data files, the research conducted an analysis which attempts to control for factors which do not appear to be associated with the introduction of fixed payments. Thus, Table 4 shows the statistically estimated average proportion of cases concluding at each stage in all of Scotland's 49 Sheriff Summary courts. It includes the introduction of mandatory intermediate diets (IDs) in 1996 as key component of the table below. Therefore, Table 4 shows the impact of introduction of mandatory intermediate diets separately prior to the introduction of fixed payments.

In interviews it was widely observed by defence solicitors and fiscals that the proportion of cases resolving at the Intermediate Diet has increased as a result of the structuring of fixed payments. For example:

The most economic use of fixed fees is simply to plead everybody not guilty, apply for legal aid, get legal aid granted, then plead them all guilty in the Intermediate Diet. [Stakeholder face-to-face follow-up interview 6, defence solicitor]

70 Goriely et al., n. 2; Tata et al., n. 2

71 The research investigated whether during the period 1997-2003 there had been major changes of policy or practice in summary procedure; patterns of cases being brought and prosecuted through the summary courts. The only one which appears to have had a major overall impact has been the introduction of mandatory intermediate diets which is discussed later. Various other possible hypotheses were proposed by members of the research advisory group to see whether they may have instead caused any changes in the patterns of case trajectories. These included: the introduction of statutory racial aggravation; human rights challenges; the increased use of prosecutor fines and other forms of diversion from prosecution; transfer of cases from the Sheriff to the District Courts or different case mixes. Most appeared to have had relatively negligible impact overall and none would appear to have had a major impact. For further explanation of the investigation of these alternative hypotheses, see Stephen and Tata, op. cit., n. 49. 
Table 4: Cases resolving under time and line and under fixed payments at four stages ${ }^{72}$

\begin{tabular}{lllll}
\hline & $\begin{array}{l}\text { \% Pleading } \\
\text { Diet }\end{array}$ & $\begin{array}{l}\text { \% Intermediate } \\
\text { Diet }\end{array}$ & $\begin{array}{l}\text { \% Day } \\
\text { of Trial }\end{array}$ & \% Trial \\
\hline $\begin{array}{l}\text { Under Time \& Line } \\
(1990 / 1-1995 / 6)\end{array}$ & 63.35 & 4.15 & 21.15 & 11.36 \\
$\begin{array}{l}\text { Under Time \& Line } \\
\text { plus mand. IDs }\end{array}$ & 59.71 & 12.57 & 17.13 & 10.58 \\
$\begin{array}{l}\text { Under fixed payments } \\
\text { plus mand. IDs }\end{array}$ & 56.88 & 16.22 & & \\
$(1999 / 2000-2002 / 3)$ & & & 18.22 & 8.67 \\
\hline
\end{tabular}

There's more pleas at the Intermediate Diet or at the trial diet ... I mean it used to be ... the sky was the limit for them wasn't it? ... They'd have been quite happy to sit about in court until half past three, four o'clock because they were getting paid for it. Now they're not, they want to be out doing other things, so they're more inclined to plead now. [Procurator fiscal depute, follow-up face-to-face interview]

Telephone and face-to-face interviews defence solicitors emphasized that although the impact of fixed payments may have had some bearing on pleading advice this, they said, did not mean that clients could were unduly pressured:

If somebody was wanting to go to trial they would be going to trial whether there was a fixed fee or not. [Telephone survey defence solicitor 981366]

Rather, although the impact of fixed fees has changed pleading advice and the incentive is clear, the change in pleading advice could not be unequivocally regarded detrimental to clients' interests:

I can see that, eh, if you know that you are going to get $£ 500$ for a case that could be resolved at the beginning but equally it might be resolved with no eh worse position for the client [...] then obviously there is an incentive there. [Stakeholder Interview 2 Defence Solicitor]

72 These percentages in Table 4 are not simple arithmetic averages but are estimates derived from statistical analysis which aimed to take control for extraneous differences between individual courts (for example, prosecution practices). For a detailed discussion of the statistical method see id., App. C.

73 The analysis takes account of the statistical impact of mandatory intermediate diets from their introduction until 2002/3.

74 Statistically, the impact of the introductions of mandatory intermediate diets and of fixed payments were isolated from each other so as to measure any the impact separately. The results show unambiguously that the introduction of both fixed payments and intermediate diets has in themselves (as well as in combination) had a significant impact on case trajectories. Detailed analysis is given in Stepehen and Tata, op. cit., n. 49, especially App. C. 
Furthermore, as suggested by ethical indeterminacy, pleading decisions were said to be shaped by a subtle interplay of factors, especially where clients were uncertain as to how to plead and did not give clear instructions. Solicitors were aware of the optimal financial arrangements (plead not guilty at the pleading diet and then guilty at the intermediate diet), but (as suggested by ethical indeterminacy) this could not be definitively regarded as contrary to client wishes or interests:

[Defence solicitors] want to get pleas sorted out ... at Intermediate Diets ... I'm not saying they were spun out before, but it maybe focuses people's attention - if something's going to be a [guilty] plea, it should be a plea at the Intermediate Diet. If it's not going to be a [guilty] plea then you continue onto trial, you go to trial. All of that is driven by the client as well, you can't force someone into pleading guilty at the Intermediate Diet just because that suits you financially. But you're aware of how the plea is tendered. So solicitors, from their point of view, they'd probably wish to have matters resolved sooner rather than later. But that's always at the end of the day dictated by the client. But certainly it's in your mind, you know why bother pleading guilty at the trial - if it's an adjusted plea you can adjust that plea at the Intermediate Diet do it sooner, it's only a few weeks but still. [sic. Stake-holder Defence solicitor face-to-face interview 7]

An increase in the proportion of cases resolving at the intermediate diet was said to have been a deliberate intention of the government and SLAB which wanted to see earlier guilty pleas:

Under time and line system there was no encouragement to plead early if there was indeed going to be a plea, so there was no reason to do it other than on the day of trial. So one of the things we were hoping for by stacking the payments the way we did was to encourage earlier pleas at Intermediate Diet because we recognised there were actually savings - not for summary legal aid - but there were savings elsewhere in the system in terms of court time, inconvenience to witnesses etc. [Stakeholder Interview 5 SLAB Official]

However, other effects unanticipated by the architects of the fixed fees policy have resulted, overall, in later guilty pleas. For example, fixed payments appear also to have had the effect of adding further to the existing system disincentives to plead guilty at the first opportunity (the pleading diet). ${ }^{75}$ There appears to have been a 2.8 per cent decrease in the proportion of cases concluding at the pleading diet. Figure 1 plots the change in the proportion of cases concluding at the pleading diet and corresponding confidence intervals.

Consequently, 78 per cent of the net increase in cases concluding at the intermediate diet is a result of the net reduction in the proportion concluding at the pleading diet. In other words, the introduction of fixed payments has had a net postponing effect (exactly the reverse of what proponents of fixed payments had expected to see).

75 See, also, Samuel, op. cit., n. 13; Goriely et al., op. cit., n. 2; Tata et al., op. cit., n. 2. 
Figure 1. Sheriff Summary Courts: Cases Concluding at Pleading Diet

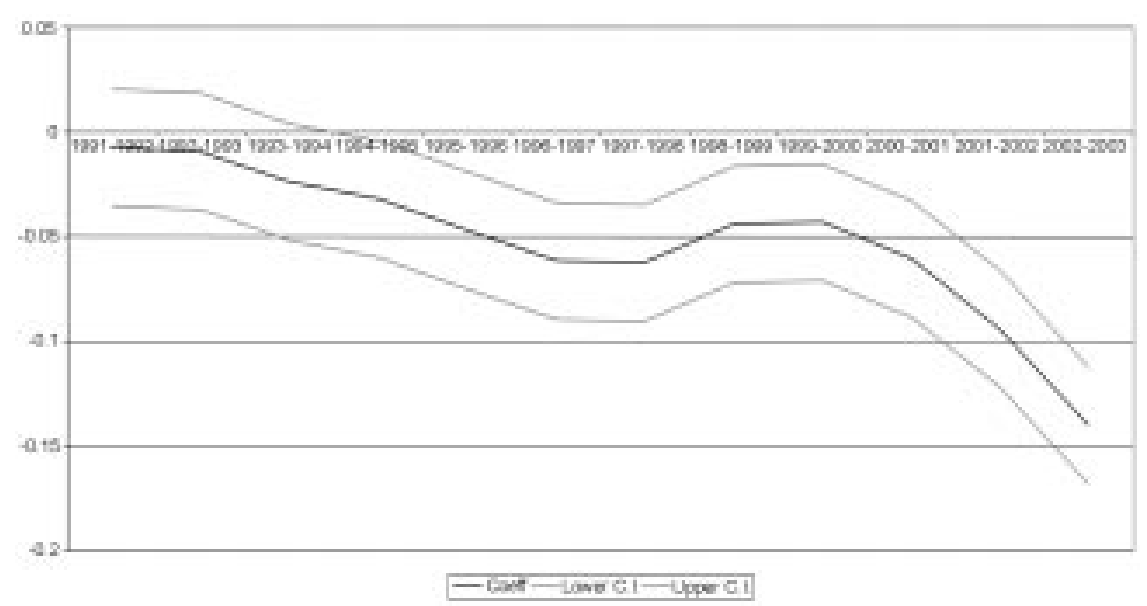

As suggested by the concept of ethical indeterminacy, here a defence solicitor explains why advising a plea of not guilty at the pleading diet can be regarded from an adversarial perspective of quality to be both in the financial interests of the solicitor and of the client:

[I]f you've got a client who appears from custody charged with various offences - if he pleads guilty [at the Pleading Diet] you'll probably earn a maximum of $£ 25$, which is the minimum fee for appearing. If he pleads not guilty, immediately you've got $£ 500$. There is no benefit to anyone in pleading guilty [at the Pleading Diet]. I mean he's then not being effectively represented ... If you want professional representation you have to plead not guilty [at the Pleading Diet]. [Non -stakeholder defence solicitor face-to-face interview 1]

There appears to have been a second unforeseen effect of the impact of fixed payments: this is the proportions of cases resolving on the day of trial. There was no statistically significant decrease in the percentage of 'cracked' trials (that is, those which conclude on the day of trial but before evidence has been led), and if anything a slight apparent increase. Figure 2 shows the confidence intervals for the regression analysis of cases concluding on the day of trial but without evidence being led. It shows that the proportions of cases concluding on the day of trial had been falling since the early 1990s (a trend which gathered pace from the mid 1990s to 1999). ${ }^{76}$ The decline in the proportion of cases concluding on day of trial reversed in the year 19992000 (the year of the introduction of fixed payments).

Why might fixed payments have led to no decrease (and possibly even a minor increase) in the proportions of cases concluding on the day of trial?

76 This may be attributable to the introduction of mandatory intermediate diets. See Stephen and Tata, op. cit., n. 49, for separate analysis of the effects of mandatory intermediate diets and fixed payments. 


\section{Figure 2. Sheriff Summary Courts: Cases Concluding on Day of Trial}

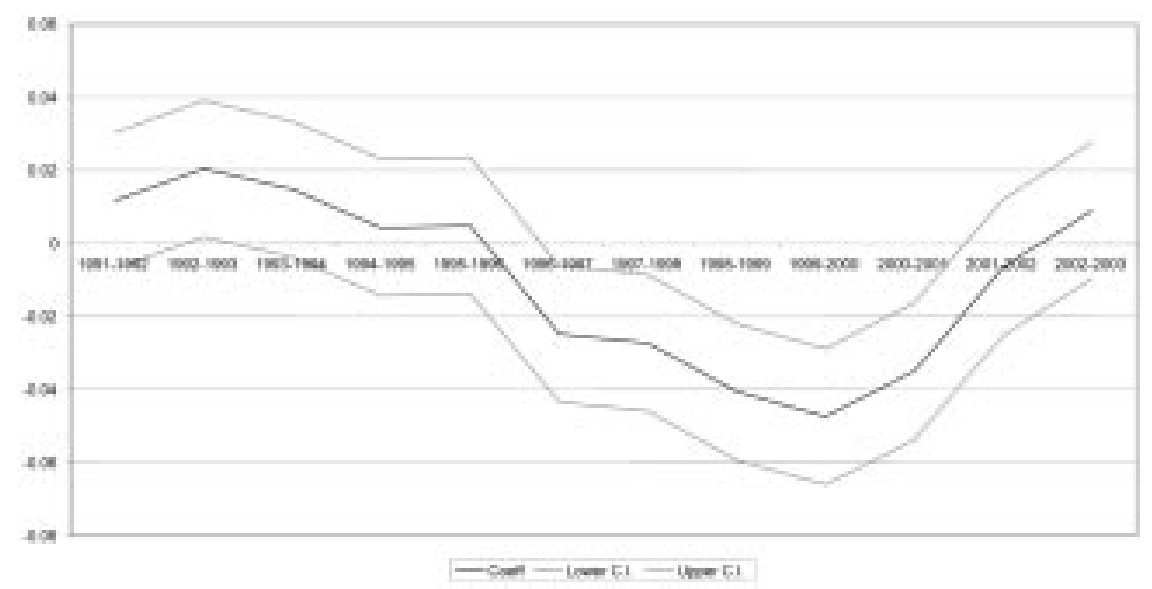

One reason, it is commonly said, why accused persons do not plead guilty immediately is because they wish to "put off the inevitable. ${ }^{77}$ While this may be a factor, advising an accused person to maintain a plea of not guilty at least until the day of trial is, from an adversarial perspective of quality and need, a rational strategy. Defence solicitors and depute fiscals (prosecutors) said that, aside from changes in remuneration structures, the best time to have the chance to talk to the fiscal about the case was on the day of trial. Indeed this is often seen as 'the best time to put on the screws'. ${ }^{78}$ Moreover, the chance that the prosecution case may fold increases substantially if the case continues to the day of trial: ${ }^{79}$

Other things being equal, an accused's best means of avoiding a conviction is to maintain a not guilty plea at least until the morning of the trial and preferably beyond. The chance that the prosecution case will fold is small but real, and contrasts with the certainty of conviction if one pleads guilty. ${ }^{80}$

Thus, in spite of the financial incentives of the fixed payments structure, there remain strong adversarial reasons for advising clients to not plead guilty at the intermediate diet so as to wait until the day of trial.

Yet, while from an adversarial perspective there are strong reasons to maintain a plea of guilty until the day of trial, this does not in itself explain why the introduction of fixed payments appears not to have led to any

77 For example, see accounts reported in P. Pleasence and H. Quirk, The Criminal Case Profiling Study (2001).

78 Goriely et al., op. cit., n. 2.

79 Indeed, prosecution interviews for the fixed payments research indicated an awareness of routine 'over-charging' until the fiscal had a chance to examine the evidence more closely just before trial.

80 Goriely et al., op. cit., n. 2, pp. 97-8. 
decrease (and indeed a slight increase) in the share of cases which resolve on the day of trial. Indeed, it was widely recognized by defence solicitors and fiscals that there is no commercial advantage in continuing a case to trial or even the morning of the trial - from a purely financial point of view, the optimal time to plead guilty is at the intermediate diet. For example:

You are more keen to have a case resolved that will resolve at an Intermediate Diet as opposed to going to trial on it because there is no financial benefit as such in going to trial even if there was a legal benefit in going to trial. [Telephone Interview, defence solicitor]

However, ethical indeterminacy reminds us that financial considerations tend to mesh with other considerations of self-interest. Thus, one potential explanation for the apparent slight increase in cracked trials relates to the reduced amount of time which defence agents said that they now have to examine the case against the accused prior to the intermediate diet. As we saw earlier, there seems to have been a sharp decline in the amount of time which solicitors have to examine the case and the level of client contact. Therefore, if, at the time of the intermediate diet, the defence solicitor has not had enough time to examine the case or discuss it with the client, it will be more likely that, in cases where the accused is unsure whether she or he should change his or her plea, and evidence is either not available or not straightforward, for the solicitor to suggest to the client that it would be better (at least in adversarial terms) to plead not guilty and wait and see how the prosecution responds. ${ }^{81}$ Prosecutors, for instance, observed a change in defence tactics as a result of the reduction in client contact and preparation. For example:

I think this business of them not having contact with their clients is a difficulty 'coz they're not in a position to say [...] so a lot of them say, 'not guilty'. [Stakeholder Interview 12 COPFS]

What we sometimes see happening is defence agents go through an Intermediate Diet and say 'we are fully prepared and ready to proceed to trial.' But on the day of the trial they will sidle up to you and say, 'Gi'e us a look at your statements because I don't have any', which basically means that they haven't been in a position where they wanted to go to trial. They haven't been precognosing. [Stake-holder Interview 14, COPFS]

In their accounts of their changing practices, defence solicitors combined bureaucratic-efficiency imperatives with a nod towards adversarialism and client-centred values to explain why the loss of precognitions makes earlier

81 Note that these figures largely pre-date the position of the Court of Criminal Appeal from October 2003 onwards (in Du Plooy v. HM Advocate) that sentencers should state openly whether or not they are giving a discount for an early guilty plea and the extent of any such discount. However, there is no clear evidence to show whether or not the case law has actually led to a more widespread practice of discounting for an early guilty plea than before, or, simply to a greater degree of transparency. See, also, F. Leverick, 'Making Sense of Sentence Discounting' (2003) Scots Law Times 267-71. 
guilty pleas harder to achieve. Advising a client could not be achieved without some knowledge of the case:

where the client told you the position was basically a not guilty and without the evidence to say to them, 'well hang on a second that doesn't make any sense.' Sometimes clients who are under the influence of drink or drugs and have managed to come up with a memory of it that is totally at odds with what happened, but I don't have any statements so I can't confront them with them [... and] sit them down and say 'see what you told me before, that's just complete rubbish. Here's what the statements are' and at that point they may very well agree to change the plea ... [Stakeholder Interview 2 defence solicitor]

Advising a client to plead guilty could not be done without some knowledge of the case:

You can't wrestle your client to the ground and say, 'look you're being prosecuted, therefore you must have done it and you must plead guilty.' That flies in the face of any idea of what a defence agent's job should be. You take your client at face value initially. If evidence comes out that shows what your client told you initially is not the case, then you present it to the client for an explanation. [face-to-face non-stakeholder defence solicitor interview 7]

In other words, fixed payments have made it more difficult for defence lawyers to achieve early guilty pleas. Client contact and preparation appear, overall, to aid the delivery of guilty pleas (that is, the opposite of what proponents of fixed payments had supposed).

Thus, it can be regarded as a realistic option in many cases, where the accused is unsure how to plead, to advise the accused to maintain a plea of guilty until the day of trial. Although a higher fee cannot be claimed for waiting until trial to tender a guilty plea, the level of effort is often little more than it would be if tendering a guilty plea at the intermediate diet, and indeed there is the increased chance that the prosecution's case will fold. Therefore, the multiplicity of ways of conceiving of the client's best interests allows a plea of guilty at the intermediate diet to be equally 'ethical' as a plea on the morning of the day of trial.

As we have seen, one of main the aims of the fixed payments policy (achieving greater 'efficiency' by encouraging earlier guilty pleas) has been undermined by other intended effects of the policy (for example, a reduction in client contact and case preparation, particularly the use of precognitions). Not only has the fixed payments policy failed to deliver earlier guilty pleas, it has, overall, had the opposite effect: a net postponing effect. However, one would expect that clients who plead guilty earlier than they otherwise will benefit by receiving a more lenient sentence - a question to which we now turn.

\section{Guilty plea sentence discounting}

Ethical indeterminacy in plea advice decision-making is further facilitated by the indeterminacy of sentence discounting. One might assume that an accused person will normally receive greater credit for an earlier guilty plea 
(at the pleading diet or at intermediate diet) than later (on the morning of trial or, indeed, if convicted after trial) and it should therefore clearly be in the interests of a client who is going to plead guilty anyway to do so earlier. However, the vagaries of sentence discounting mean that the prediction of whether or not a discount will be given is very much a matter for the lawyer to advise the client. In Scotland, the extent of any discount for a plea of guilty depends on the stage and circumstances of any plea in each individual case and there is no requirement on sentencers to give a discount. ${ }^{82}$

However, in October 2003, the Appeal Court in Scotland issued the $D u$ Plooy guideline judgment ${ }^{83}$ which said that there should be greater transparency in sentence discounting so that those accused who would be pleading guilty anyway could be encouraged to do so earlier. The decision as to whether or not a discount is to be applied in any particular case remains essentially permissive: it depends on the facts, circumstances and timing of any plea. Sentencers are not bound to apply a discount. Greater transparency is to be achieved by the sentencing judge stating in open court the extent to which he or she has discounted the sentence where a discount is 'appropriate'. However, this transparency is complicated by uncertainty and mediated by the accused person's lawyer.

A further crucial variant which defence solicitors have to consider is intersentencer sentencing disparity not only of sentencers' starting points but also in the approach to the application of discounting. ${ }^{84}$ In the fixed payments research, it was widely reported by defence lawyers and prosecutors that such disparity undermined the expressed utilitarian aim of the $D u$ Plooy judgment by opening further opportunities for 'sheriff-shopping' ${ }^{85}$ Sheriffshopping also presents defence lawyers with an opportunity to advise clients to plead at a point which is both convenient to the defence solicitor and simultaneously seen to be in the best interests of the client. ${ }^{86}$

82 Research comparing samples of similar cases in the period found that there did not appear to have been any widespread practice of guilty plea discounting, although interviews with accused persons suggested that the expectation of a near automatic discount was widespread. Accused persons may, therefore, have pled guilty partly in the mistaken expectation of a discount (Tata et al., op. cit., $\mathrm{n} \mathrm{.2)}$ ).

83 Du Plooy (Devonne) v. HM Advocate (no. 1) 2003 SCCR 443.

84 This and other research (Tata, op. cit., n. 66) found that sentencers interpret Du Plooy in distinctly different ways.

85 'Sheriff - (or judge-) shopping' is the tactical practice of attempting to choose (or shop around for) a more favourable sentencer by, for example, seeking an adjournment in the hope of coming before a different sentencer.

86 C. Tata, 'Sentencing as Craftwork and the Binary Epistemologies of the Discretionary Decision Process' (2007) 16 Social \& Legal Studies 425-47. 


\section{IMPLICATIONS: IS THE 'SUPPLY'/‘DEMAND' DICHOTOMY SUSTAINABLE?}

The concept of ethical indeterminacy may contribute to the debate between the supplier-induced demand thesis and demand-induced supply thesis. It may be useful to distinguish between narrow and broader versions of ethical indeterminacy. A relatively narrow version of ethical indeterminacy suggests that it is possible reconcile both theses. Lawyers operate with a range of influences: not only financial but also cultural, ideological, and organizational. ${ }^{87} \mathrm{~A}$ narrow version of the concept of ethical indeterminacy suggests that where the decision as to how to advise a client is in the balance and different courses of action could be argued to be equally beneficial, the lawyer is more likely to advise the client to make a decision which is in the lawyer's own interests (commercial being one of these).

A broader version of ethical indeterminacy, however, brings into question the very idea of supply-side and demand-side theses. Both theses share in common a way of conceiving, describing, and evaluating criminal legal services. They operate on the basis of an abstract dichotomous relationship between two sides: 'supply' and 'demand'. The research discussed in this paper appears to point to the possibility that, although talk of supply and demand is sound in the abstract, close empirical scrutiny suggests that it may be impossible to distinguish one from the other.

'Need' (demand) is not an inert entity which is simply 'out there' in each case to be responded to by lawyers. Rather, as so much of criminal process research has shown, lawyers (like others in the process) create and construct cases. By interpreting, selecting, and advising, defence lawyers, like other professionals, construct case stories and 'facts'. Inevitably and necessarily, lawyers constitute 'need' and 'demand'. Thus, it may not be practically possible definitively to identify 'real need'.

However, both supply-side and demand-side theses assume that cases have inherent and essential needs. For example, McGuire et al. define 'supplier-induced demand' as:

the supplier, in acting as agent for the consumer, brings about a level of consumption different from that which would have occurred if a fully informed consumer had been able to choose freely. ${ }^{8}$

Thus, if we to be able to measure or even conceive of supplier-induced demand, we must have some conception, however hazy or implicit, of

87 This helps to explain why, although the fixed payments environment has brought about significant change, one should not expect to see complete change even where there is a radical change in payment structures. Guilty plea practices, for instance, are driven by a range of synergistic influences - not simply nor mainly financial.

88 McGuire et al., The Economics of Health Care (1998), emphasis added, quoted in Bevan, op. cit., n. 3, p. 104. Likewise, Gray et al., op. cit., n. ??, p. 547, n. 3 argue that lawyers 'manipulate ... the amount of work done ... independently of the case requirements.' 
completely free and 'fully informed' choice: the correct decision based on the client's real best interests, free of 'extraneous' effects or incentives. There is an implicit conception of what the client would do if s/he had 'perfect information': a completely free choice. ${ }^{89}$ Indeed, the limitations of understanding 'real' demand appear to be because professionals define ${ }^{90}$ and thus are necessarily constitutive of demand.

Cape and Moorhead have exposed the implicit moral censure of defence lawyers behind the supplier-induced demand hypothesis: '[T]he supplierinduced demand thesis has been used to discredit professional judgements about what clients need ...' 91 Yet a 'demand-induced supply' thesis must also assume some knowable basic idea of what is necessary or needed. ${ }^{92}$ The demand-induced supply thesis supposes that it is both logical and inevitable that lawyer activity must necessarily have increased because there is more need (as generated by activity of the state). Yet, if 'need' is an inescapably shifting and indeterminate construction (because shifting perspectives operate to define it), then changes in state activity will not inevitably produce closely corresponding changes in spending on defence work.

Both the supplier-induced demand and the demand-induced supply theses operate on an implicit essentialist conception of need. Concepts such as 'efficiency' and 'value for money' imply some notion of adequate value and therefore 'real' need. The difference between the two theses is whether lawyers tend to do 'too much', 'too little', or 'about right' levels of work which are needed for different cases. Economists try explicitly to calculate the 'optimal' timing at which to incentivize the giving of a guilty plea. ${ }^{93}$ Indeed, all efficiency studies of the courts rely on (a usually implicit) idea of what 'real' demand/need based on some notion of what demand there would be if consumers were 'fully informed' and 'free' of 'extraneous incentives'. This 'if' is not simply deeply hypothetical, but sociologically-speaking simply untenable. It suggests a notion of consciousness (in this case of clients/consumers) which is wholly distinct from its social basis.

Both 'supply-side and demand-side theses implicitly view cases through the lens of legal formalism: the true 'facts' of each case are definitive,

89 Bevan, id., fleetingly recognizes the intractable difficulty of identifying real demand: 'The comparison is thus of an actual with an unattainable ideal.' However, this does not preclude an analysis which advances that thesis. Bevan's position notwithstanding, my point is that the supplier-induced demand thesis necessitates some sort of conception of 'real' demand.

90 For example, L.Burzotta Nilson, 'An Application of the Occupational Uncertainty Principle to the Professions' (1979) 26 Social Problems 570-81.

91 Cape and Moorhead, op. cit., n. 8, at p. 9. See, also, Bridges, op. cit., n. 8.

92 This does not discount the fact that individual authors who have advocated either thesis might also advance a less essentialist position. Rather, my purpose here is to concentrate on the idea which is inherently fundamental to supply/demand theses.

93 For example, Stephen, op. cit., n. 37, pp. 23-41; N. Garoupa 'The Theory of Optimal Law Enforcement' (1997) 11 J. of Economic Surveys 267-95. 
objectively knowable, and waiting to be found. 'Need' is be regarded positivistically: as somehow 'out there'; inert; and waiting to be discovered. Both theses operate on the assumption that there is a basic, real demand in criminal cases.

We have seen that the move from a 'time and line' (or proportional) system to a fixed payment system has impacted on defence work. It has led to a sharp decline in client contact; and in preparation especially precognition and a reliance instead on summaries of the evidence. Different conceptions of 'need' underlie assessments about whether precognitions and client contact was 'over-supplied'. As we saw from the data, while a change in remuneration structures did lead to a change in the timing of guilty pleas, there were also limits to this. Overall, it was not possible for solicitors to coerce or browbeat clients into pleading guilty, especially where the solicitor had little knowledge of the case to draw on (from lack of: prosecution disclosure, client contact, and precognitions/preparation) to persuade clients to plead guilty. So the control which lawyers can exert has its limits. In addition, we should recall that financial drivers are by no means the only incentives at play: lawyers are also deeply concerned with other forms of social and cultural capital. For instance, 'the credibility with colleagues and judges is crucial to their professional survival.' 94

Clients' expressed wishes (their desired outcomes) do not make up a neat, inert entity which is just there to waiting to be responded to. ${ }^{95}$ These wishes

94 Mather et al., op. cit., n. 19, at p. 307; P. Tague, 'Barristers' Selfish Reasons in Counselling Defendants over the Choice of Plea' (2007) 53 Crim. Law Rev. 3-23.

95 For example, in an oft-cited paper, (M. Cain 'The General Practice Lawyer and the Client' (1979) 7 International J. of the Sociology of Law 331-54), Cain's account of her findings emphasises the clarity and specificity of clients' objectives: clients in her sample generally knew what they wanted. She makes a simple distinction between means and ends: 'Clients do know and are entitled to know what they want; a good lawyer will achieve an exact translation of this in another discursive realm ... [M]ost clients tell their solicitor what they want and he sets about getting for them' (at 340, original emphasis). In Cain's account, clients know their 'destination' and the lawyer (as 'translator') works out the most effective route. However, while it may be important to emphasize, as Cain has done, that lawyers do not simply bully their clients (and in this way facilitate repressive social relations in more insidious ways than supposed by a simple lawyer domination model), a neat division between objective (or destination) and method (or route) has seemed more blurred in other research with civil clients. 'In contrast to the neat division of labour ... most of the [divorce] lawyers we interviewed described how they attempted to influence both the route and the destination of their clients' cases' (Mather et al., op. cit., n. 19 at p. 287, original emphasis retained). In the fixed payments research and also in contemporaneous research on the process report writing, clients demonstrated little of the certainty and clarity of Cain's civil clients. Indeed the ephemeral character of many defendants' objectives are nicely illustrated by a passing remark by Cain (p. 346) describing (approvingly) a lawyer who 'accepted the client's wish to "get off" as his objective'). But what does it mean to 'get off'? Achieving a favourable result for sure, but what exactly? A reduced charge? A sentence discount for a guilty plea? An 
are, among other things, inescapably wrapped up with the work of the lawyer. Although both the 'supplier-induced demand' and the 'demandinduced supply' argue that there is a relationship between supply and demand, they nonetheless regard 'supply' and 'demand' as fairly settled and discrete entities - there is 'real' demand which can be seen as distinct from supply. My suggestion is that supply and demand are inescapably and mutually constitutive.

All of this means that it may be practically impossible to state any definitive advantage or disadvantage to pleading guilty at any particular point in the process since such a decision is contingent on an almost infinite assortment of variables - variables which are themselves elusive and indeterminate. Nor does it seem possible to determine empirically whether or not a reduction in client contact and preparation (brought about by fixed payments) can be shown definitively to be contrary to client interests. I do not mean to suggest that it is impossible in the abstract to arrive at the 'best interests' of clients but, rather, that because lawyers are the daily custodians of legal knowledge, practical experience, and the keepers and masons of individual case 'facts', the search to define and fix a pure conception of best interests (and thus 'need') which is free of and 'uncontaminated' by other influences (not least the lawyer) may be empirically unrealizable. There is no unmediated essence of a case to which we can fix universal definitive characteristics of 'need'.

effective plea in mitigation? Complete acquittal? Adjournment? What is deemed to be favourable by the client ('get off') can only be understood in terms of clients' (managed) expectations. See, also, Tata, op. cit., n. 66. 